\title{
Evaluation of the Efficacy of Plant Materials for the Control of Flea Beetles Podagrica spp on Okra Abelmoschus esculentus L
}

\author{
*DANJUMA, S; MUHAMMED, I; YAHAYA, G \\ Department of Crop Production, Faculty of Agriculture, Ibrahim Badamasi Babangida University, Lapai, P. M. B. 11, Niger State, Nigeria \\ *Corresponding Author Email: sdanjuma@gmail.com
}

\begin{abstract}
The efficacy of the Senegal prickly-ash Zanthoxylum zanthoxyloides (Lam.) roots and the African locust bean tree Parkia biglobosa (Jacq.) pod back was study for their efficacy in the control of okra pest, Podagrica spp. The study was carried out in the laboratory and on the field in the farming season of 2018. Z. zanthoxyloides roots were obtained from Jima-Doko forest and P. biglibosa fruit back from Takunpara. Both plant materials were air-dried under shade for 120 hours. Both plant parts were pounded separately in wooden mortar with the aid of wooden pestle until the materials turns to fine particles. Determined weight of 100, 150, 200, 250, and 300 grams were taken for each plant materials and soaked in water for 24 hours and stirred at intervals of an hour. The mixture were then sieved with a muslin cloth and filtered with Whatman filter paper to eliminate all finest particles of varying sizes. These concentrations were applied individually on 10 adults of Podagrica spp. in the laboratory. It was observed that the concentration of $200-300 \mathrm{~g}$ performed better for both plant materials in the control of okra flea beetle. These resulted to the death of above $50 \%$ of the insect within 2 hours. These significant laboratory trials were then formulated and taken to the field. Both plant materials acted as anti-feedants and repellants against Podagrica spp. It was also revealed that $Z$. zanthoxyloides performed significantly $(p<0.05)$ better than the P. biglibosa. Furthermore, short interval applications (<or=3days) of these plant materials could be a good replacement for synthetic chemicals, hence bio-pesticides that could be adopted for organic agriculture.
\end{abstract}

\section{DOI: https://dx.doi.org/10.4314/jasem.v25i4.6}

Copyright: Copyright (C) 2021 Danjuma et al. This is an open access article distributed under the Creative Commons Attribution License (CCL), which permits unrestricted use, distribution, and reproduction in any medium, provided the original work is properly cited.

Dates: Received: 12 December 2020; Revised: 26 January 2021; Accepted: 12 February 2021

Keywords: Senegal prickly-ash, African locust bean pod, Okra, Podagrica spp., Anti-feedants, Repellants

Okra plays an important role in the human diet (Kahlon et al. 2007; Saifullah and Rabbani 2009) by supplying fats, proteins, carbohydrates, phosphorus, calcium, iron, sulphur, fibre, minerals and vitamins (Gopalan et al. 2007; Arapitsas 2008; Dilruba et al., 2009; Gemede et al., 2015). Industrially, okra mucilage is usually used for glace paper production and also has a confectionery use. Okra has found medical application as a plasma replacement or blood volume expander (Adetuyi et al. 2008; Kumar et al. 2010). Its medicinal value has also been reported in curing ulcers and relief from hemorrhoids (Gemede $e t$ al., 2015). Tests conducted in China suggest that an alcohol extract of okra leaves can eliminate oxygen free radicals, alleviate renal tubular-interstitial diseases, reduce proteinuria, and improve renal function (Liu et al., 2005; Kumar et al. 2009). In Lapai, Niger State, Nigeria, the fresh unripe and tender pods (fruits) are sliced, grated, boiled, steamed or fried and beat into a glutinous soup. This soup facilitates the swallowing of relatively rough or coarse textured starchy food. The major limiting factor of okra production are pests and diseases such as flea beetle, cotton stainer, aphids, thrips, grasshopper, and the diseases include, leaf spot, bacterial wilt, root-knot nematode, powdery mildew and early blight are associated with okra (Venkataravanappa et al., 2013b). Okra is vulnerable to insect pests during all stages of growth, however, severe damage is noticed especially during vegetative stage (Fasunwon and Banjo, 2010; Alao et al., 2011). Insect pests are a major setback for commercial production of the crop (Hugar and Palled 2008; Ijoyah and Jimba, 2012). Among the insect pests that cause economic damage on the crop, the flea beetles (Podagrica spp.) (Coleoptera, Chrysomelidae) is the most serious in the recent times (Ahmed et al., 2007; Clementine et al., 2009; Fasunwon and Banjo, 2010). It has been constantly observed as the major pests of okra among plants in the Malvaceae family (Modupe, 2010), infesting leaves leading to considerable economic yield losses (Degri and Richard, 2014; Fasunwon and Banjo, 2010). Defoliation due to flea beetle infestations has been reported to be up to $80 \%$ and severity of damage varies in different places (Clementine et al., 2009). The activities of flea beetles drastically reduce the 
photosynthetic capacity of the leaf resulting in low dry matter production and consequently, low yield (Thul et al., 2009). It has been reported that flea beetles are responsible for the transmission of Okra Mosaic Virus (OMV) observed in Nigeria, Kenya, Sierra Leone, Cote d'Ivoire (Fajinmi and Fajinmi 2010; Askira and Degri, 2012). Due to the destructive activities of the flea beetle, their management becomes imperative in order to achieve and maintain yields. In the past, various control measures have been adopted, such as use of insecticides (Meenambigai and Bhuvaneswari, 2017). Generally synthetic insecticides are the most effective means due to their quick action and long lasting effects (Ahmed et al., 2007). Unfortunately, environmental pollution, resistance to insecticides and the high cost of pesticides which are beyond the reach of the illiterate and poor-resource farmers has limit the adoption and application of most insecticides (Ukoima and Okah, 2006; Nderitu et al., 2008). There is need to assess some control measures that would be environmentally friendly, less costly, easy to apply and easy to adopt (Benson, 2017). Although the use of synthetic and botanical insecticides for the control of Podagrica spp. has been reported in Nigeria, but there is paucity of information on the effect of P. biglobosa and Z. zanthoxyloides aqueous extract for the purpose of managing Podagrica spp. on okra. Therefore a more economical and no hazard to human and his environment are required to manage these persistent pests. Furthermore, organic production of this vegetable is required to ensure that people eat more safe okra. Hence, a botanical approach was designed by this study to handle the control of flea beetles on okra. This study will enhance farmers and pest manager in the further formulation of better control strategies that are ecologically friendly and pose no danger to human existence.

\section{MATERIALS AND METHODS}

Study area: The study was carried out at the Department of Crop Production Laboratory, and the Teaching and Research Farm of the Faculty of Agriculture, Ibrahim Badamasi Babangida University (IBBU), Lapai.

Insect culture: Adult flea beetles from okra fields were collected from Teaching and Research Farm of the IBBU, Lapai. These were released on potted okra plants in nylon mesh cages $(40 \times 40 \times 40 \mathrm{~cm})$ for ovipositions. The released adults were removed at 18 days after their release on the caged of potted plants and observed daily for adult emergence on the infested pots. Adult were seen to emerge at 35 days after the initial parent stocks were removed from the cultured cages. The emerged adults were used for all the experiments, which were conducted in the laboratory at room temperature $\left(25-28^{\circ} \mathrm{C}\right)$ and $75-80 \%$ relative humidity. The rearing protocol follows the work of Oke and Odebiyi (2008).

Okro planting for the experiments: Okro seeds were planted in pots, 5 seeds per pot and after germination, okro seedlings were thinned to 3 stands of high vigour of okro plant per pot. These seedling were screened against insect pests with the aid cages of 40 X 40 X 40 $\mathrm{cm}^{2}$ and $1 \mathrm{X} 1 \mathrm{X} 1 \mathrm{~m}^{2}$ covered with nylon mesh for laboratory and field trials, respectively. For the two experimental categories, the okro plants were used at the age of 2 weeks after planting.

Preparation of plant materials: Z. zanthoxyloides root was harvested from the Zhima - Doko forest and $P$. biglobosa pod was harvested from Takunpara all in Niger state. The back of the root of Z. zanthoxyloides were peeled and the back of the pod of P. biglobosa was also peeled and all air dried individually under shade for the period of 120 hours. The plant materials were then pounded in wooden mortar with the aid of wooden pestle separately till they turned into fine particles. These were sieved to further obtain the finest particles.

Preparation of the aqueous extracts of the plant materials: The weight of $100 \mathrm{~g}, 150 \mathrm{~g}, 200 \mathrm{~g}, 250 \mathrm{~g}$ and $300 \mathrm{~g}$ of the plant materials were separately dissolved in a litre of water each for the period of 24 hours. The mixture was stirred at intervals with the aid of a stirring rod. Mixtures per weight for each plant materials were then sieved with muslin cloth to collect the liquid extracts. Each plant extracts were further being cleaned of fine particles by filtering with Whatman filter paper.

Laboratory trials: Each of the treatments (100g, 150g, $200 \mathrm{~g}, 250 \mathrm{~g}$ and $300 \mathrm{~g}$ ) was replicated 3 times using a cage of 40 X $40 \times 40 \mathrm{~cm}$ and potted okra plants covered with nylon net in the laboratory at $25-28^{\circ} \mathrm{C}$ at $75-78 \%$ RH. $5 \mathrm{ml}$ of the extract was taken with the aid of syringe and needle and was used to spray the okra plants within the cages and at 30 minutes, 10 adults flea beetles of 5 days old were introduced into the cages and observed at an hour intervals till they died or becomes weak.

Field trials: The weight of $200 \mathrm{~g}, 250 \mathrm{~g}$, and $300 \mathrm{~g}$ were prepared for field trials $(100 \mathrm{~g}$ and $150 \mathrm{~g}$ were excluded because they did not revealed any visible impacts on the control of insects). The cage of $1 \mathrm{X} 1 \mathrm{X} 1 \mathrm{~m}^{2}$ covered with nylon net was used on the field with 3 potted okra plants ( 3 per pot) within. These treatments were also replicated 3 times. The okra plants were 
sprayed separately with $15 \mathrm{ml}$ of the treatments and 20 flea beetles were introduced in each cage. These were observed at 3 hours interval and records of death and live flea beetles were taken.

Okro leaf damage categorization: Five (5) points Visual Damage Scale was developed to categorize the damaged (numbers of holes) observed on the okro leaves. The scale was categorized as thus:

1. Undamaged ( 0 hole $\left./ \mathrm{cm}^{2}\right)$

2. Light damage (up to 2 hole $/ \mathrm{cm}^{2}$ )

3. Medium damage (3-4 hole $/ \mathrm{cm}^{2}$ )

4. Medium - high damage (5-9 hole $\left./ \mathrm{cm}^{2}\right)$ with physical damage of the leaf surface

5. Severely damage: when leaf surface is physically damaged and the number of holes are no longer countable

Control: Two controls were set for the field trials;

a. Control sprayed with the test botanicals and without insect introduction (CONTROL A).

b. Control devoid of test botanical spray but infested with insect (CONTROL B).

Data analysis: Numbers of damaged leaves were categorized using 5 point scale and leaves damaged pattern discussed. Numbers of surviving and dead flea beetles were converted by using square root to meet the assumption of Analysis of variance. Then the data were analyze using the statistical tool of GenStat version 10.3DE (2011) Ltd. (Rothamsted experimental station).

\section{RESULTS AND DISCUSSION}

Laboratory trials: The laboratory trials of the aqueous extracts were conducted at the Crop Production Department for both plant materials. Records of impacts of $Z$. zanthoxyloides and P. biglobosa were taken for every hour till there was no effect or total mortality was observed on the experimental insect. The results of the trials were presented in tables $1 \mathrm{a}$ and 1b. For both plants materials there was progressive mortality observed. Insect mortality increases with increase in numbers of hours and later stabilized as the power of the plant materials reduces due to exposure and availability of air. In an hour exposure of the experimental insect to the treated okro plants, 1 and 2.22 mortality was observed for $100 \mathrm{~g}$ and $150 \mathrm{~g}, 4.13$, 5.96, and 8.84 mortalities were observed for $200 \mathrm{~g}$, 250 , and $300 \mathrm{~g}$, respectively for the okro plants treated with Z. zanthoxyloides (table 1a). Contrarily, 0.00 mortality was observed for $100 \mathrm{~g}$ and $150 \mathrm{~g}, 1.34,2.09$, and 3.25 mortalities for $200 \mathrm{~g}, 250 \mathrm{~g}$ and $300 \mathrm{~g}$, respectively for the okro plants treated with $P$. biglibosa (table 1a). Summarily, the Z. zanthoxyloides was more active and posed more dangerous impacts than $P$. boglobosa on the experimental insects.

Table 1a: Number of death Podagrica spp. after an hour of exposure to okra treated with plant materials

\begin{tabular}{llllll}
\hline \multicolumn{5}{c}{$\boldsymbol{T}(\boldsymbol{g})$} \\
\hline Plant materials & 100 & 150 & 200 & 250 & 300 \\
\hline Zanthoxyloides & $1.00 \mathrm{a}$ & $2.22 \mathrm{a}$ & $4.13 a$ & $5.96 a$ & $8.84 a$
\end{tabular}

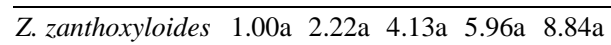

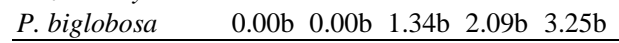

Means in the column followed by the different small letters are significantly different ( $p<0.05) ; T(g)$ is treatments (aqueous solution extracted from 100 - $300 \mathrm{~g}$ of plant material); All figures are means of 3 replicates

Table 1b Number of death Podagrica spp. after two hours of exposure to okra treated with plant materials

\begin{tabular}{llllll}
\hline \multicolumn{5}{c}{$\boldsymbol{T}(\boldsymbol{g})$} \\
\hline Plant materials & 100 & 150 & 200 & 250 & 300
\end{tabular}

Z. zanthoxyloides 5.63a 7.76a 10.00a 10.00a 10.00a \begin{tabular}{llll} 
P. biglobosa $\quad 0.00 \mathrm{~b} 1.20 \mathrm{~b} 5.34 \mathrm{~b}$ & $6.21 \mathrm{~b} \quad 6.56 \mathrm{~b}$ \\
\hline
\end{tabular}

Means in the column followed by the different small letters are significantly different ( $p<0.05) ; T(g)$ is treatments (aqueous solution extracted from $100-300 \mathrm{~g}$ of plant material). All figures are means of 3 replicates

The experiment insects were also observed for two hours and mortality records was also taken. The result is presented in table $1 \mathrm{~b}$. Similar trend of mortalities as observed for an hour experiment was also observed for the 2 hours experiment. At the end of 2 hours observations, 5.63 and 7.76 mortalities were observed for $100 \mathrm{~g}$ and $150 \mathrm{~g}$, and 10.00 were observed for $200 \mathrm{~g}$, $250 \mathrm{~g}$ and $300 \mathrm{~g}$ of okro plants treated with $Z$. znthoxyloides, respectively (table 1b). Similar lower mortality trends were observed on okro plants reated with P. biglibosa. 0.00 and 1.20 mortalities for $100 \mathrm{~g}$ and $150 \mathrm{~g}$, and 5.34, 6.21 and 6.56 mortalities for 200g, $250 \mathrm{~g}$ and $300 \mathrm{~g}$ respectively (table $1 \mathrm{~b}$ ). From the laboratory trials for the two hours test with 10 insects each, Z. zanthoxyloides exact more mortality pressures on the tested insect and P. biglibosa exact lower trends of mortality on the tested insect. Although the two botanicals tested had a similar impact, $Z$. zanthoxyloides performed significantly better than $P$. biglibosa $(p<0.05)$ at all times tested at determined different quantities. Apart from mortality observed for the test, experimental insects were also observed either hanging on the nylon net used to cover the cages or resting on the treated okro plants unable to feed till they drop off and died.

Field trials: The means of dead Podagrica spp. after three regimes of spray (5 days interval) with $Z$. zanthoxyloides plant extract was presented in table $2 \mathrm{a}$. Significant progressive deaths of Podagrica spp. were revealed from the first spray to the third spray for all the categories of the treatments $(200 \mathrm{~g}, 250 \mathrm{~g}$ and $300 \mathrm{~g}$ ) (table 2a). Similarly, increase in plant extract (Treatment $(Z . z) g$ ) also lead to significant increase in 
Podagrica spp. death. It was observed that $200 \mathrm{~g}$ of the plant extract resulted in less number of insect death and thereafter increasing death were observed for the $2^{\text {nd }}$ and $3^{\text {rd }}$ regimes of sprays, similar trends of death was also observed for the $250 \mathrm{~g}$ and $300 \mathrm{~g}$ for regimes of sprays, respectively (table $2 \mathrm{a}$ ). the observed death scenario were significantly different for all the treatments and the order of significant is presented as thus $300 \mathrm{~g}>250 \mathrm{~g}>200 \mathrm{~g}$, respectively. In the same vein, the spray regimes were also observed to present the same pattern of significance with $3^{\text {rd }}$ spay resulting in highest death, followed by the $2^{\text {nd }}$ spray and least was observed for the $1^{\text {st }}$ spray (table $2 \mathrm{a}$ ).

Table 2a: Means (3 replicates) of dead Podagrica spp. after

\begin{tabular}{|c|c|c|c|}
\hline \multicolumn{2}{|c|}{ Treatment $1^{\text {st }}$} & \multirow{2}{*}{$\begin{array}{l}2^{\text {nd }} \\
\text { spray }\end{array}$} & \multirow{2}{*}{$\begin{array}{l}3^{\text {rd }} \\
\text { spray }\end{array}$} \\
\hline (Z.z)g & spray & & \\
\hline 200 & $3.32 \mathrm{C}$ & $6.03 \mathrm{Cb}$ & $\overline{10.33 \mathrm{Ca}}$ \\
\hline 250 & $7.67 \mathrm{~B}$ & $12.67 \mathrm{Bb}$ & $14.43 \mathrm{Ba}$ \\
\hline 300 & $9.71 \mathrm{~A}$ & $15.10 \mathrm{Ab}$ & $17.30 \mathrm{Aa}$ \\
\hline $\mathrm{SE} \pm$ & 0.667 & 0.609 & 0.385 \\
\hline LSD & 1.6311 & 1.489 & 0.942 \\
\hline
\end{tabular}

Means followed by different small letters in the rows and those followed by different capital letters in the column were significantly different $(p<0.05)$

Table 2b: Means (3 replicates) of dead Podagrica spp after spraying with $P$. biglobosa

\begin{tabular}{|c|c|c|c|}
\hline \multicolumn{2}{|c|}{ Treatment 1st } & $\begin{array}{l}\text { 2nd } \\
\text { spray }\end{array}$ & $\begin{array}{l}\text { 3rd } \\
\text { spray }\end{array}$ \\
\hline 200 & $2.13 \mathrm{C}$ & $4.61 \mathrm{Bt}$ & $8.00 \mathrm{Ba}$ \\
\hline 250 & $3.07 \mathrm{~B}$ & $2 \mathrm{Al}$ & $11.55 \mathrm{Aa}$ \\
\hline 300 & $6.67 \mathrm{~A}$ & c $8.33 \mathrm{Al}$ & $11.57 \mathrm{Aa}$ \\
\hline SE \pm & 0.272 & 0.272 & 0.145 \\
\hline LSD & 0.756 & 0.756 & 0.756 \\
\hline
\end{tabular}

Means followed by different small letters in the rows and those followed by different capital letters in the column were significantly different $(p<0.05)$

The means of dead Podagrica spp. observed after three regimes of spray (5 days interval) with $P$. biglibosa plant extract were presented in table $2 b$. With reference to spray regimes, significant progressive deaths of Podagrica spp. were observed for all the three treatments $(200 \mathrm{~g}, 250 \mathrm{~g}$ and $300 \mathrm{~g})$. Least death of the insects was observed for the first spray and an increasing death observed for the $2^{\text {nd }}$ and $3^{\text {rd }}$ sprays (table 2b). Comparing the treatments, $300 \mathrm{~g}$ performed significantly better than $250 \mathrm{~g}$ and $200 \mathrm{~g}$. $250 \mathrm{~g}$ also performed significantly better than the $200 \mathrm{~g}$ in the $1^{\text {st }}$ spray. In the $2^{\text {nd }}$ spray, no significant different was observed between the death of Podagrica spp. observed for $250 \mathrm{~g}$ and $300 \mathrm{~g}$ of the treatments, but these two were significantly different for the death exacted on the insect by $200 \mathrm{~g}$ of the treatment (table $2 b)$. Similarly, the same trend as observed in the $2^{\text {nd }}$ spray was also repeated in the $3^{\text {rd }}$ spray where there was no significance difference observed between $250 \mathrm{~g}$ and $300 \mathrm{~g}$, but these two treatments were better than the death exacted on Podagrica spp (table 2b). Feeding holes on okro plant leaves treated with $Z$. zanthoxyloides presented decreasing feeding lesion from those plants treated with $200 \mathrm{~g}-300 \mathrm{~g}$ (table $3 \mathrm{a}$ ). More holes were observed on the plants treated with extract from $200 \mathrm{~g}$ and the number of holes observed on plants treated with $250 \mathrm{~g}$ and $300 \mathrm{~g}$ of the extracts were significantly less and presented in this order; $200 \mathrm{~g}>250 \mathrm{~g}>300 \mathrm{~g}$ (table 3a). The means observed for the three regimes spray were of the same patterns of more feeding lesions on leaves of okro plants treated with $200 \mathrm{~g}$ and less holes on $250 \mathrm{~g}$ and $300 \mathrm{~g}$. All these were significantly different (table $3 \mathrm{a}$ ). The range of feeding holes was $1-3.93$ holes observed from highest treatment $(300 \mathrm{~g})$ to the lowest treatment $(200 \mathrm{~g})$. These range of holes lead to the categorization of damage as light damage to medium damage.

Table 3a: Means (3 replicates) of Feeding holes on okro leaves after spray with $Z$. zanthoxyloides

\begin{tabular}{llll}
\hline Treatment $(\boldsymbol{Z} . \boldsymbol{z}) \mathbf{g}$ & 1st spray & 2nd spray & 3rd spray \\
\hline 200 & $3.67 \mathrm{c}$ & $3.93 \mathrm{c}$ & $3.93 \mathrm{c}$ \\
250 & $2.22 \mathrm{~b}$ & $2.36 \mathrm{~b}$ & $2.37 \mathrm{~b}$ \\
300 & $1.00 \mathrm{a}$ & $1.67 \mathrm{a}$ & $1.74 \mathrm{a}$ \\
SE \pm & 0.77 & 0.054 & 0.385 \\
LSD & 1.884 & 2.579 & 0.942 \\
\hline eans followed by different small letters in the same column are \\
\multicolumn{4}{r}{ significantly different $(p<0.05)$}
\end{tabular}

Table 3b: Means (3 replicates) of Feeding holes on okra leaves after spray with $P$. biglobosa

\begin{tabular}{llll}
\hline Treatment $(\boldsymbol{P} . \boldsymbol{b}) \mathbf{g}$ & 1st spray & 2nd spray & 3rd spray \\
\hline 200 & $6.33 \mathrm{a}$ & $8.37 \mathrm{c}$ & $10.08 \mathrm{c}$ \\
250 & $5.90 \mathrm{~b}$ & $5.93 \mathrm{~b}$ & $5.97 \mathrm{~b}$ \\
300 & $4.67 \mathrm{~b}$ & $4.67 \mathrm{~b}$ & $4.73 \mathrm{~b}$ \\
SE \pm & 0.333 & 0.544 & 0.471 \\
LSD & 0.925 & 1.511 & 1.309 \\
\hline Means followed by different small letters in the same column are \\
significantly different $(p<0.05)$
\end{tabular}

Feeding holes on okro plant leaves treated with $P$. biglobosa is presented in table $3 \mathrm{~b}$. Comparing the treatments in the columns for the sprays, this showed that plants treated with the extracts from $200 \mathrm{~g}$ suffers more and were fed on by the insects and this was evident from the means of holes on the okro leaves. Less holes were observed on okro plant leaves treated with extracts from the $250 \mathrm{~g}$ and $300 \mathrm{~g}$. These two treatments present no significant difference from the means of holes observed on them. But these were significantly different from means of holes observed on the okro plants treated with extracts from $200 \mathrm{~g}$ (table 3b). The categorization of the holes range observed was from 4.46 - 10.08 holes per leaf (table $3 b)$. These were described as medium damage to medium high damage with physical destruction of the leaf surface. From the forgoing presentation of the number of holes, it was revealed that okro plant treated with Z. zanthoxyloides extract suffered less damage 
when compared to the okro plant treated with $P$. biglibosa extract. This is evident from the mean number of holes / damages revealed from the two extracts performance.

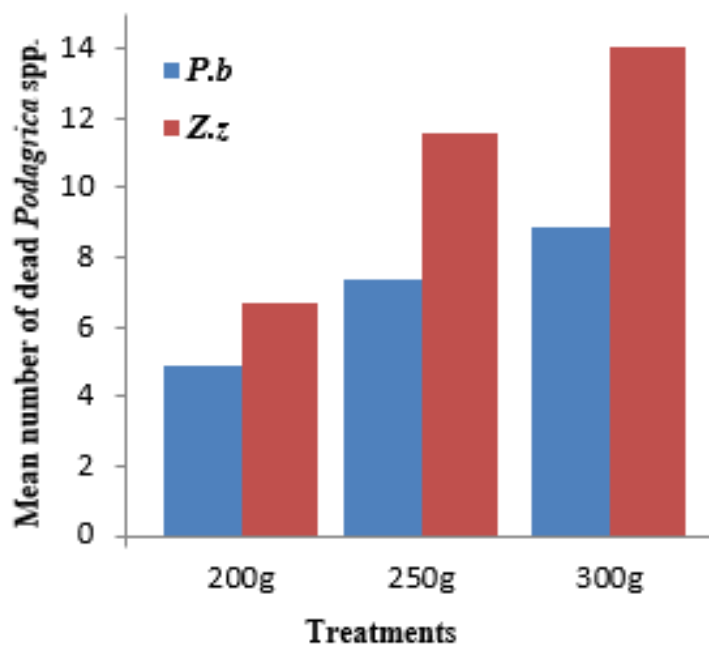

Fig 1: Mean (3 replicates) number of dead Podagrica spp. observed from the application of $P . b$ and Z.z. Where; P.b $=$ Parkia biglobosa and Z.z = Zanthoxylum zanthoxyloides

Comparison between $P$. biglobosa and $Z$. zanthoxyloides extracts impact on the mean number of dead Podagrica spp. was presented with the aid of a graph (Figure 1). For all the categories of treatments $(200 \mathrm{~g}, 250 \mathrm{~g}$ and $300 \mathrm{~g})$ bars observed, it was revealed that $Z$. zanthoxyloides extracts lead to more death on the test insects than was observed for $P$. biglibosa extracts (figure 1). The mean number of deaths observed for all the categories of treatments were significantly different $(p<0.05)$. Furthermore, the mean number of dead insects continues to increase with increase in the grams of the botanical (200g $300 \mathrm{~g}$ ) extracts for both botanical category (figure 1).

The categories of control revealed contrary results. It was observed from CONTROL A that the okro plants were not damaged and the plants were very healthy and of high vigour. CONTROL $\mathrm{B}$, revealed a okro plants that were damaged beyond categorization based on feeding lesion, and Podagrica were flourishing without death cases recorded for the period of the observation.

The study has shown the potential of Z. zanthoxyloides and $P$. biglobosa in controlling the Podagrica insect pests of okro. The roots of $Z$. zanthoxyloides and husk of $P$. biglobosa pod exhibited different levels of insecticidal properties against Podagrica insect pests of okro. The extracts from $Z$. zanthoxyloides and $P$. biglobosa have been used as natural pesticides against different pests and diseases due to the phytochemicals present in different parts of the plant (Fayinminnu et al., 2017; Osabutey et al., 2018). But the roots of $Z$. zanthoxyloides and husk of $P$. biglobosa were less reported in text. Some studies showed that aqueous extract of $P$. biglobosa pod husk contained the highest number of phytochemicals of all the plant parts studied. The phytochemicals include phenols, flavonoids, tannin, saponin, cardiac glycoside, steroid, terpenoid, alkaloid and anthraquinone (Abagale et al., 2013) and those isolated from $Z$. zanthoxyloides so far include alkaloids, aliphatic and aromatic amides, lignans, coumarins, sterols, carbohydrate residues, saponin etc (Adesina, 2005). All these phytochemicals properties especially saponins are responsible for the pesticidal activities of the two botanicals studied. $Z$. zanthoxyloides from the present study was more potent on the studied insect than P. biglobosa. This may be due to more concentration of the phytochemicals in $Z$. zanthoxyloides than those present in P. biglobosa. However, Z. zanthoxyloides have been reported to be effective against other pests due to the presence of one of the constituent secondary metabolites, Zanthoxylol which is a phenolic compound reputed for insecticidal activity (1998). At lower concentrations of comparison, Z. zanthoxyloides show high pesticidal potentials than $P$. biglobosa. Similar trend of high pesticidal potentials was also revealed at high concentrations of $Z$. zanthoxyloides. Although this was expected, but fast knockdown within short period were observed than was observed for P. biglobosa. The low insecticidal potentials observed for P. biglobosa could be due to the low concentration of saponin in the aqueous pod husk extract. De Geyter et al. (2007) reported that Saponin possesses insecticidal activity that causes mortality. Other reason could be due to the method of extraction which may lead to lower release of some of the phytochemicals contents that are responsible for insect pest limitation. From the forgoing, the two studied plant materials act as botanical repellants and antifeedants, thus influencing insect's locomotion, oviposition, feeding behavior, developmental and physiological processes as well as behavioral patterns (Osabutey et al., 2018).

Conclusion: Different parts of Z. zanthoxyloides (leaf and stem) have been researched into testing for their pesticidal impact on insect pests, but there is little information on it root. Although P. biglobosa pod husk has been in use for decades as fish poison by fishermen, there is also paucity of information in text about this plant pesticidal activity. Therefore, further research need to be carried out to ascertain its properties as a potentials botanical for the control of insect pests. Conclusively, the two plant materials have the potentials to control insect pests on agricultural crops. 
Acknowledgement: The researchers wish to thank Mr. Mathew Chori a laboratory technologist that helped in so many innumerable ways with reference to the technical aspect of the research ranging from obtaining the plant materials, processing and extractions of the chemical components of the tested plants.

\section{REFERENCES}

Abagale, S. A., Twumasi, S. K. and Awudza, J. A. (2013). Chemical analyses of aqueous extract of Parkia biglobosa fruit husk collected from Northern Ghana. Acad. J. 8(14):589-595

Adesina, SK (2005). The Nigerian Zanthoxylum: Chemical and biological values. Afr. J. Trad. Comp. Alt. Med. 2(3): $282-301$

Adetuyi, F; Ajala, L; Ibrahim, T (2008). Effect of the addition of defatted okra seed (abelmoschus esculentus) flour on the chemical composition, functional properties and $\mathrm{zn}$ bioavailability of plantain (Musa paradisiacal L.) flour. JMBFS. 2 (1) 69-82.

Ahmed, BI; Yusuf, S; Yusuf, AU; Aliyu, M (2007). Comparative efficacy of different concentrations of some promising insecticides for the control of podagrica spp (coleoptera: Chrysomelidae) on Okra (Abelmoschus esculentus (L.) Moench). Glo. J. Agri. Sc. 6, 31-34

Alao, JS; Sale, FA; Ojo, AS (2011). Problems and management of insect pests in social forestry in Nigeria. Afr. J. Agr. Res. 6 (33), 6755-6758.

Arapitsas, P (2008). Identification and quantification of polyphenol compounds from okra seeds and skin. Food Chem. 110: 1041-1045.

Benson, GAS (2017). Efficacy of Selected Insecticides and Botanicals in the Control of Field Insect Pest of Okra (Abelmoschus esculentus) in Akure. Int. J. For. Hort. (IJFH) 3: 4, 2017. 1-5

Dabiré-Binso, C; Malick, N; Somé, K; Antoine, S (2009). Preliminary studies on incidence of insect pest on okra, Abelmoschus esculentus (L.) Moench in central Burkina Faso. Afri. J. Agr. Res. 4(12):1488-1492.

De Geyter, E; Geelen, D; Smagghe, G; (2007). First results on the insecticidal action of saponins. Com. Agric. Appl. Bio. Sc., Ghent University. 72(3):645-648.
Degri, MM; Richard, IB (2014). Impact of Intercropping Sorghum and Okra on the Incidence of Flea Beetles of Okra Podagrica spp in Dalwa, Maiduguri Semi-Arid Zone of Nigeria. Intl. Let. Nat. Sc.14:51-58

Dilruba, S; Mirza, H; Karim, R; Kamrun, N (2009) Yield Response of Okra to Different Sowing Time and Application of Growth Hormones. J. Hort. Sc. Orna. Pl. 1 (1): 10-14.

Fajinmi, AA; Fajinmi, OB (2010). Incidence of okra mosaic virus at different growth stages of okra plants (Abelmoschus esculentus L. Moench) under tropical condition. J. Gen. Mol. Virol. 2(1):028031.

Fasunwon, BT; Banjo, AD (2010). Seasonal Population Fluctuations of Podagrica Sp on Okra Plant Abelmoschus esculentus (L.) Moench. Res. J. Agr. Bio. Sc. 6, 283-288.

Fayinminnu, OO; Adeniyi, OO; Alabi, OY; Omobusuyi, DO (2017). Potentials of Aqueous Extract of Pod Husk Parkia biglobosa (Jacq.) Benth as a Biopesticide in Okra (Abelmoschus esculentus (L.) Moench) Production. J. Agri.Ecol. Res. Int. 12(1): 1-12

Gemede, H. F., Ratta, N., Haki, G. D., Woldegiorgis, A. Z. and Beyene, F. (2015) Nutritional Quality and Health Benefits of Okra (Abelmoschus esculentus): A Review. J Food Process Technol. 6: 458

Gopalan, C; Sastri, V; Balasubramanian, SC (2007). Nutritive value of Indian foods, National Institute of Nutrition, ICMR, Hyderabad, pp 18, 19, 24 and 29

Hugar, HY; Palled, YB (2008). Studies on MaizeVegetable intercropping systems. Karnataka J. Agr. Sc. 21:162-164

Ijoyah, MO; Jimba, J (2012). "Evaluation of yield and yield components of maize (Zea mays L) and okra (Abelmoschus esculentus L. Moench) intercropping system at Makurdi, Nigeria”, $J$. Biodiv. Environ. Sc. 2(2), 38-44.

Kahlon, TS; Chapman, MH; Smith, GE (2007). In vitro binding of bile acids by okra beets asparagus eggplant turnips green beans carrots and cauliflower. Food Chem. 103: 676-680. 
Kumar, R; Patil, MB; Patil, SR; Paschapur, MS (2009). Evaluation of Abelmoschus esculentus mucilage as paracetamol suspension. Intl. J. Pharm. Tech. Res. 1:658-665.

Kumar, S; Dagnoko, S; Haougui, S; Ratnadass, A; Pasternak, D; Kouame, C (2010). Okra (Abelmoschus spp.) in West and Central Africa: potential and progress on its improvement. Afr J Agric Res. 5:3590-3598.

Liu, IM; Liou, SS; Lan, TW; Hsu, FL; Cheng, JT (2005). Myricetin as the active principle of Abelmoschus moschatusto lower plasma glucosein streptozotocin-induced diabetic rats. Planta Medica. 71: 617-621.

Meenambigai, C; Bhuvaneswari, K (2017). Pesticides usage pattern of okra, Abelmoschus esculentus (L) Moench in Tamil Nadu. J. Entomol. Zool. Stud. 5(6): 1760-1765

Modupe, MA (2010). Host preference in family Malvaceae by Podagrica spp. (Coleoptera: Chrysomelidae): An oligophagus herbivore.

Nderitu, JH; Kasina, JM; Kimenju, JW; Malenge, F (2008). Evaluation of Synthetic and Neem-Based Insecticides for Managing Aphids on Okra (Malvaceae) in Eastern Kenya. J. Entomol. 5: 207-212.

Ogunwolu, EO; Igoli, JO; Longs, NN (1998). Reduction in reproductive fitness of Callosobruchus maculatus F. exposed to Zanthoxylum zanthoxyloides (Lam.) Waterm [J]. J. Herbs Spp. Med Pl., 6: 19-27
Oke, OA; Odebiyi, JA (2008). Rearing procedure for the pre-imaginal stages of the flea beetle (Podagrica sjostedti) (Coleoptera: Chrysomelidae), and its developmental biology on okra (Abelmoschus esculentus). Intl. J. Trop. Ins. Sc. 28: (3) 151-157

Osabutey, AF; Eziah, V; Buxton, T; Owusu EO (2018). Evaluating the insecticidal potential of aqueous plant extracts from Zanthoxylum zanthoxyloides and Anacardium occidentale against insect pest complexes of cabbage in an open field experiment. Intl. J. Agr. Sc. Res. 7(3). 018-027.

Saifullah, M; Rabbani, MG (2009). Evaluation and Characterization of Okra (Abelmoschus esculentus L. Moench.) Genotypes. SAARC J. Agr. 7, 92-99.

Thul, SR; Patil, RS; Mule, RS (2009). Field efficacy of some pesticides against flea beetle (Podagrica bowringi Baly. Coleoptera: Chrysomelidae) infesting okra. J. Maharashtra Agr. Univ., 34: 5759

Ukoima, HN; Okah, A (2006). Use of some Biopesticides in Controlling Pests and Diseases of Okra (Abelmuscus esculentus). Ecol. Environ. Conserv. 24(94): 781-783.

Venkataravanappa, V; Reddy, CNL; Jalali, S; Reddy, MK (2013b). Molecular characterization of a new species of begomovirus associated with yellow vein mosaic of bhendi (okra) in Bhubhaneswar, India. Eur. J. Pl. Pathol. 136, 811-822 